\title{
Mahasiswa dan Internet: Dua Sisi Mata Uang? Problematic Internet Use pada Mahasiswa
}

\author{
Reinaldo, Yasinta Astin Sokang ${ }^{1}$ \\ Fakultas Psikologi Universitas Kristen Krida Wacana
}

\begin{abstract}
Problematic Internet Use (PIU) is one of the negative effects of the internet use, but we can rarely find publications on PIU of Indonesian's college students, especially college students in Jakarta. The purpose of this research was to describe PIU among college students in Jakarta. The Generalized Problematic Internet Use Scale 2 was used to collect data of a total of 474 college students from three universities in Jakarta. The results showed that: a) For preference for online social interaction symptoms, participants preferred to do online social interaction rather than face to face interaction, especially when face to face interactions were not possible. b) For mood regulation symptoms, participants used internet to regulate their negative feelings. c) For cognitive preoccupation symptoms, participants tended to have obsessive thought patterns for their activity on internet. d) For compulsive internet use symptoms, participants found it difficult to restrict their internet use. e) For negative outcome symptoms, online activities of participants did not have negative influence on their daily routines. Furthermore, the results showed no significant differences of the PIU symptoms across gender and internet use duration. Taken together, the results indicated moderate level of problematic internet use in our sample.
\end{abstract}

Keywords: college students, gpius 2, problematic internet use, Jakarta.

Abstrak. Problematic Internet Use (PIU) adalah salah satu efek negatif penggunaan internet, tetapi kita jarang menemukan publikasi mengenai PIU pada mahasiswa di Indonesia, terutama pada mahasiswa di Jakarta. Untuk itu, penelitian ini bertujuan memberikan informasi mengenai gambaran PIU pada mahasiswa di Jakarta. Generalized Problematic Internet Use Scale 2 digunakan untuk mengumpulkan data dari total 474 mahasiswa dari tiga universitas di Jakarta. Hasil penelitian menemukan bahwa: a) Gejala preferensi untuk interaksi sosial secara daring menunjukkan bahwa partisipan lebih menyukai interaksi sosial secara daring daripada interaksi tatap muka, terutama ketika interaksi tatap muka tidak mungkin dilakukan. b) Untuk gejala regulasi mood, partisipan menggunakan internet untuk mengatur perasaan negatif yang mereka rasakan. c) Untuk gejala cognitive preoccupation, partisipan cenderung memiliki pola pemikiran obsesif terkait aktivitas mereka di internet. d) Gejala penggunaan internet kompulsif menunjukkan bahwa partisipan cenderung sulit untuk membatasi penggunaan internet mereka. e) Gejala dampak negatif menunjukkan bahwa aktivitas online partisipan tidak memberikan pengaruh negatif pada rutinitas sehari-hari mereka. Lebih lanjut, hasil penelitian ini tidak menunjukkan adanya perbedaan gejala PIU yang signifikan, baik antar jenis kelamin maupun lama penggunaan internet. Secara bersamasama, hasil penelitian ini mengindikasikan adanya PIU pada tingkat moderat yang dialami partisipan penelitian ini.

Kata kunci: Jakarta, gpius 2, mahasiswa, problematic internet use (piu)

\footnotetext{
1 Korespondensi mengenai isi artikel ini dapat dilakukan melalui: reinaldo.2012fpsi011@civitas.ukrida.ac.id, astinsokang@ukrida.ac.id
} 
Teknologi dapat membawa kemudahan dan juga dapat menjadi sumber masalah bagi individu (Young, 1996), dan internet adalah salah satu contohnya. Problematic Internet Use (PIU) adalah istilah yang menunjukkan dampak negatif penggunaan internet (Young, 1998; Caplan, 2003; Shapira, Lessig, Goldsmith et al., 2003; Murali \& George, 2007). Young (1997) mengungkapkan bahwa PIU adalah penggunaan internet untuk berbagai aktivitas daring (online) yang dilakukan secara berlebihan sampai ke tahap yang dapat memberikan dampak negatif bagi kondisi fisik, kesehatan psikologis, lingkungan sosial, kemampuan akademis, relasi dengan individu lain, dan berbagai area kehidupan lainnya. Caplan (2010) mengelompokkan gejala utama PIU menjadi empat gejala utama, yaitu: preference for online social interaction (POSI), mood regulation, deficient self-regulation (cognitive preoccupation \& compulsive internet use), dan negative outcome. Pengukuran PIU menggunakan Generalized Problematic Internet Use Scale 2 (GPIUS2).

Berbagai penelitian menunjukkan bahwa fenomena PIU umumnya terjadi pada mahasiswa (Scherer, 1997; Kandell, 1998; Chou, Condron, \& Belland, 2005; Mossbarger, 2008). Sekitar 4-10\% mahasiswa memiliki potensi besar untuk mengalami gejala PIU (Chou, Condron, \& Belland, 2005; Czincz \& Hechanova, 2009). Hal ini juga didukung oleh kemudahan untuk mendapatkan akses internet baik secara kabel maupun nirkabel (wireless atau wi-fi) dan akses internet yang tidak dipungut biaya di kampus (Moore, 1995). Selain itu, tuntutan perkuliahan untuk menggunakan media internet sebagai prasyarat pelaksanaan studi (Scherer, 1997) membuat mahasiswa menggunakan internet dalam aktivitas kesehariannya. Di sisi lain, akses internet yang mudah didapatkan di kampus juga dimanfaatkan oleh mahasiswa untuk menghadapi masamasa sulit yang dialami selama perkuliahan (Hall \& Parsons, 2001). Kuatnya kecenderungan mahasiswa untuk menggunakan internet dan menggunakan berbagai aplikasi berbasis daring, membuat populasi ini sesuai untuk studi mengenai PIU.

Penelitian mengenai PIU umumnya membahas dua pokok pemikiran. Pertama, variabel PIU dikaitkan dengan aspek kesejahteraan psikologis para penggunanya (Morahan-Martin, 2007; Spada, Langston, Nikcevic \& Moneta, 2008), seperti depresi (Ybarra, Alexander \& Mitchell, 2005; Young \& Rogers, 1998), kecemasan (Caplan, 2005; Spada, Langston, Nikcevic \& Moneta, 2008; YuYuan, 2007), kesendirian (AmichaiHamburger \& Ben-Artzi, 2003; Caplan, 2002; Kubey, Lavin \& Barrows, 2001; Morahan-Martin \& Schumacher, 2000), berkurangnya kemampuan sosialisasi (Caplan, 2005), dan lain-lainnya. Kedua, gejala kognitif dan perilaku PIU berhubungan dengan interaksi sosial secara daring yang dilakukan oleh individu (Davis, 2001; Morahan-Martin, 2007), termasuk pembahasan mengenai perundungan-siber atau cyber-bullying (Ramdhani, 2016). Caplan (2003, 2005) melalui hasil penelitiannya menyatakan bahwa POSI merupakan prediktor signifikan yang membuat individu menggunakan internet secara kompulsif, hingga dapat membuat individu mengalami dampak negatif dari penggunaan internet yang berlebihan tersebut.

Berdasarkan hasil observasi dan wawancara yang telah dilakukan oleh peneliti, hampir seluruh mahasiswa menggunakan internet dalam rutinitas 
sehari-hari mereka. Beberapa mahasiswa mengakses internet melalui telepon pintar pribadi, dan ada juga mahasiswa yang menggunakan laptop atau komputer pribadinya untuk mengakses internet. Waktu penggunaan internet pun bervariasi dari satu mahasiswa ke mahasiswa yang lain, ada mahasiswa yang mengakses internet kurang lebih 5 jam per hari, 12 jam per hari, namun ada juga mahasiswa yang mengakses internet selama sehari penuh. Mahasiswa yang memiliki hobi bermain game daring bahkan dapat melakukan aktivitas tersebut sampai 'lupa waktu', tidak jarang juga sampai lupa untuk makan dan minum. Mahasiswa mengakui bahwa orangtuanya seringkali menegur agar berhenti bermain game daring, karena mahasiswa tersebut tidak memperhatikan kondisi fisiknya sendiri. Ketika sudah berhenti atau selesai bermain, mahasiswa tersebut merasa ada sesuatu yang masih bisa dan perlu dilakukan pada game daring yang dimainkan. Pemikiran ini membuat mahasiswa ingin segera memainkan game daring yang baru saja ditinggalkan. Mahasiswa tersebut pernah bermain game daring tanpa henti hingga ia lupa bahwa akan ada ujian keesokan harinya.

Hal yang umumnya dilakukan mahasiswa saat sedang mengakses internet meliputi mencari informasi jadwal kuliah, chatting, membaca berita yang sedang trend, mencari hiburan daring (menonton video dan mendengarkan musik), dan bermain game daring. Mahasiswa juga memanfaatkan internet sebagai media jual-beli daring atau online shopping. Beberapa mahasiswa mengungkapkan bahwa penggunaan internet yang dilakukan secara terus-menerus biasanya dilakukan untuk menghilangkan rasa bosan, dan mengisi waktu luang. Ketika mereka sedang tidak mengerjakan apa-apa dan merasa bosan, hampir setiap saat mereka akan menghabiskan waktu dengan mengakses internet melalui perangkat elektronik masing-masing.

Peneliti juga menemukan bahwa mahasiswa hampir tidak bisa dipisahkan dengan internet, sebab mereka akan merasa gelisah dan bosan jika tidak dapat mengakses internet. Tidak adanya akses internet akan membuat mahasiswa kesulitan untuk mencari informasi-informasi yang dibutuhkan, dan bahkan sulit untuk terhubung dengan orang lain (sulit berinteraksi dengan orang lain). Mahasiswa yang menggunakan internet sebagai media untuk menuangkan perasaan yang tidak menyenangkan juga banyak ditemukan. Luapan perasaan tersebut dituangkan melalui postingan status pada media sosial miliknya, yang dapat berupa ungkapan curahan hati atau berupa sindiran. Hal tersebut dilakukan untuk menarik simpati dari teman di sosial media sehingga tidak merasakan emosi tersebut sendirian.

Berbagai penelitian mengenai PIU telah dilakukan sebelumnya pada mahasiswa di berbagai negara seperti Pakistan (Suhail \& Bargess, 2006), Turkey (Özcan \& Buzlu, 2007), Taiwan (Chen \& Peng, 2008), dan USA - Cina (Zhang, Amos, \& McDowell, 2008), akan tetapi tidak banyak publikasi mengenai fenomena PIU pada mahasiswa di Indonesia. Penelitian ini diharapkan mampu menjadi sumber acuan demi pengembangan ilmu psikologi, khususnya cyberpsychology serta memperkaya pemahaman mengenai PIU pada mahasiswa di Indonesia. Artikel ini melaporkan hasil penelitian mengenai gambaran PIU pada mahasiswa di Indonesia, khususnya di Jakarta.

\section{Problematic Internet Use (PIU)}

Problematic Internet Use (PIU) adalah sindrom multidimensional yang terdiri 
dari gejala kognitif, emosional, dan perilaku yang mengakibatkan seseorang kesulitan dalam mengelola kehidupannya pada saat offline (Caplan, Williams \& Yee, 2009). Davis (2002) menyatakan bahwa PIU adalah suatu kondisi psikiatris pada individu yang mencakup pikiran maladaptif dan perilaku patologis. Young (1997) mengungkapkan bahwa PIU adalah penggunaan internet untuk melakukan berbagai aktivitas daring secara berlebihan sampai ke tahap yang dapat memberikan dampak negatif bagi kondisi fisik dan kesehatan psikologis; lingkungan sosial, kemampuan akademis, relasi dengan individu lain, dan berbagai area kehidupan lainnya. Jika disimpulkan, PIU adalah gejala berupa maladaptif pikiran, emosional, dan perilaku individu yang memengaruhi individu dalam menggunakan internet secara berlebihan sehingga dapat memberikan dampak negatif bagi kehidupan sehari-hari.

\section{Gejala-gejala PIU}

Caplan (2010) melalui skala GPIUS2 menjelaskan karakteristik gejala PIU sebagai berikut: Pertama, Preference for online social interaction (POSI), merupakan karakteristik individu yang percaya bahwa relasi yang dibentuk melalui internet lebih aman, nyaman, dan mudah untuk dilakukan jika dengan dibandingkan interaksi tatap muka. POSI merupakan variabel yang mempunyai peranan penting dalam perkembangan PIU (Caplan, 2003; van den Eijnden et al., 2008). Karakteristik POSI ini juga telah ditemukan berhubungan dengan aspek kognitif dan perilaku serta memberi konsekuensi negatif dari gejala PIU (Caplan, 2002). Peranan penting POSI dalam perkembangan PIU berkaitan dengan kemudahan dan kepuasan pengguna internet, untuk dapat berkomunikasi secara luwes tanpa hambatan ruang dan waktu, sehingga penggunaan internet secara berlebihan pada situs berbasis interaksi sosial secara daring dapat mengarah pada PIU (Chou \& Hsiao, 2000). Kedua, Mood regulation, merupakan gejala yang menunjukkan bahwa individu cenderung menggunakan internet untuk meregulasi emosi atau perasaan negatif yang dialami dalam kehidupan sehari-hari. Ketika individu merasakan afeksi negatif akibat aktivitas atau permasalahan dalam kehidupan sehari-hari (bosan, marah, menyesal) maka individu akan menggunakan internet untuk mengatasi afeksi negatif tersebut. Mood regulation mengacu pada penggunaan internet yang dilakukan oleh individu untuk mengurangi atau menghilangkan tekanan emosional atau perasaan-perasaan negatif yang tengah dirasakan (LaRose, Lin, \& Eastin, 2003; Spada, Langston, Nikcevic \& Moneta, 2008). Ketiga, Deficient self-regulation, gejala ini mencakup dua konsep, yaitu cognitive preoccupation (pemikiran obsesif individu terhadap hal yang dapat terjadi di internet), dan compulsive internet use (individu kesulitan untuk mengontrol keinginan menggunakan internet dalam kehidupan sehari-hari). Komponen cognitive preoccupation mencakup pemikiran yang bersifat obsesif terkait dengan penggunaan internet (Caplan \& High, 2006, Shapira et al., 2003). Excessive internet use mengacu pada kuantitas, tingkat penggunaan kegiatan daring yang melebihi batas normal penggunaan internet secara individu, sedangkan compulsive internet use mencakup kesulitan yang dirasakan individu untuk mengontrol dorongan atau impuls untuk menggunakan internet (Caplan, 2002). Keempat, Negative outcome adalah gejala yang menunjukkan bahwa penggunaan internet yang berlebihan pada individu memberikan dampak negatif pada 
kehidupan, baik mengganggu pekerjaan, kehidupan sosial, serta berbagai area kehidupan individu lainnya. Negative outcame sebagai gejala PIU mengacu pada pengaruh negatif pada pekerjaan pribadi, akademik, kehidupan personal, lingkungan sosial individu akibat penggunaan internet yang bermasalah atau berlebihan (Caplan, 2005; Morahan-Martin, 2007).

\section{Metode}

Penelitian ini menggunakan metode penelitian kuantitatif dengan pendekatan deskriptif yang menekankan analisa pada data numerikal atau angka yang diolah menggunakan metode statistika secara deskriptif (Azwar, 2013). Variabel yang diukur adalah PIU dengan menggunakan alat ukur GPIUS 2 (Generalized Problematic Internet Use Scale 2). Skala GPIUS 2 disusun dengan lima pilihan jawaban (SS, S, N, TS, STS), dengan contoh pernyataan pada tabel 1. Perhitungan statistik deskriptif yang digunakan dalam penelitian ini meliputi perhitungan mean, standar deviasi (SD), range, nilai minimum, dan maksimum.

Tabel 1

Contoh pernyataan skala

\begin{tabular}{|c|c|}
\hline Gejala & Contoh Butir Pernyataan \\
\hline $\begin{array}{l}\text { Preference for online social } \\
\text { interaction }\end{array}$ & $\begin{array}{l}\text { Saya lebih memilih interaksi sosial secara daring daripada komu- } \\
\text { nikasi secara tatap muka (face-to-face communication) } \\
\text { Interaksi sosial secara daring lebih nyaman untuk saya lakukan } \\
\text { daripada interaksi secara tatap muka }\end{array}$ \\
\hline Mood Regulation & $\begin{array}{l}\text { Saya sudah pernah menggunakan internet untuk berbicara dengan } \\
\text { orang lain ketika saya merasa terkucil } \\
\text { Saya sudah pernah menggunakan internet untuk membuat perasaan } \\
\text { saya lebih baik ketika saya merasa murung } \\
\text { Saya sudah pernah menggunakan internet untuk membuat diri saya } \\
\text { merasa lebih baik }\end{array}$ \\
\hline Cognitive Preoccupation & $\begin{array}{l}\text { Ketika saya tidak daring untuk beberapa waktu lamanya, saya } \\
\text { menjadi terus menerus berpikir untuk daring } \\
\text { Saya selalu merasa tidak bisa berbuat apa-apa bila saya tidak bisa } \\
\text { daring }\end{array}$ \\
\hline Compulsive Internet Use & $\begin{array}{l}\text { Saya mengalami kesulitan mengatur waktu yang saya habiskan } \\
\text { untuk daring } \\
\text { Saya mengalami kesulitan mengatur penggunaan internet saya } \\
\text { Ketika sedang offline, saya mengalami kesulitan melawan dorongan } \\
\text { untuk daring }\end{array}$ \\
\hline Negative Outcome & $\begin{array}{l}\text { Penggunaan internet saya membuat saya mengalami kesulitan } \\
\text { mengatur kehidupan saya } \\
\text { Saya sudah melewatkan acara-acara atau aktivitas sosial karena } \\
\text { penggunaan internet saya } \\
\text { Penggunaan internet saya menciptakan masalah-masalah dalam } \\
\text { kehidupan saya }\end{array}$ \\
\hline $\begin{array}{l}74 \text { mahasiswa dari ur } \\
\text { arakteristik partisipa } \\
\text { ertama, mahasiswa } y\end{array}$ & $\begin{array}{ll}\text { litian ini adalah } & \text { proses perkuliahan di universitas wilayah } \\
\text { rsitas di Jakarta. } & \text { Jakarta; kedua, mahasiswa yang sudah } \\
\text { enelitian adalah, } & \text { pernah mengakses internet pada kehi- } \\
\text { melaksanakan } & \text { dupan sehari-hari. }\end{array}$ \\
\hline
\end{tabular}


Penelitian ini bertujuan mengetahui apakah terdapat gejala PIU pada mahasiswa dari universitas di wilayah Jakarta sehingga populasi penelitian ini adalah mahasiswa dari universitas di wilayah Jakarta. Proses pengambilan sampel dilakukan melalui undian terhadap tujuh universitas yang ada di Jakarta dan menghasilkan tiga universitas yang menjadi tempat pengambilan sampel penelitian.

\section{Prosedur}

Skala PIU (GPIUS 2) diperoleh dari Dr. Scott E. Caplan melalui email, peneliti menerjemahkan skala menggunakan jasa UDE (Ukrida Department of English). Sampel penelitian ditentukan melalui undian simple random. Pengumpulan data dilakukan pada tiga universitas dengan total kuesioner yang terkumpul sebanyak 474 kuesioner.

\section{Uji Validitas dan Reliabilitas}

Uji validitas terhadap 15 butir pernya- taan dari skala GPIUS 2 pada penelitian ini dilakukan menggunakan Pearson Correlation, dengan hasil koefisien validitas antara 0.308-0.648. Uji Reliabilitas dilakukan dengan menggunakan Alfa Cronbach's, dengan skor koefisien sebesar 0.808 .

\section{Gambaran Umum Partisipan}

Gambaran partisipan penelitian dibagi menjadi empat bagian (tabel 2), yaitu berdasarkan usia, jenis kelamin, lama penggunaan internet, dan aktivitas dalam mengakses internet (pilihan jawaban multi-opsional, meliputi: membuka e-mail, membuka situs social media, chatting, bermain game daring, mengunduh/mengakses beragam jenis hiburan daring, mencari informasi akademis, dan online shopping).

\section{Hasil dan Pembahasan}

Internet membawa pengaruh positif dan juga negatif kepada penggunanya.

Tabel 2

Karakteristik partisipan

\begin{tabular}{llc}
\hline & Karakteristik Partisipan & Frekuensi \\
\hline Usia & $17-20$ tahun & 360 \\
& $21-26$ tahun & 114 \\
Jenis kelamin & Laki-laki & 216 \\
& Perempuan & 258 \\
Lama Penggunaan Internet & $\leq 30$ menit & 25 \\
& 30 menit - 1 jam & 69 \\
& 1 jam - 2 jam & 75 \\
& 2 jam - 3 jam & 78 \\
Aktivitas dalam mengakses & $\geq 3$ jam & 227 \\
& Chatting & 154 \\
& Membuka situs sosial media & 148 \\
& Mengunduh / menonton / mendengarkan beragam & 52 \\
& jenis hiburan daring (video, lagu, dsb) & 49 \\
& Membuka e-mail & 48 \\
& Bermain game daring & 15 \\
& Mencari informasi akademis & 8 \\
\hline
\end{tabular}


Pemakaian internet yang bijaksana dapat membawa pengaruh positif namun penyalahgunaannya dapat membawa masalah, salah satunya adalah Problematic Internet Use (PIU). Eratnya kaitan antara penggunaan internet dengan keseharian mahasiswa membuat mahasiswa memiliki kecenderungan untuk mengalami PIU, namun ketersediaan publikasi ilmiah mengenai gambaran PIU pada mahasiswa di Indonesia, khususnya mahasiswa dari universitas di Jakarta masih sangat sedikit. Hasil penelitian ini diuraikan berdasarkan hasil penelitian secara keseluruhan, lalu peneliti membahas hasil yang diperoleh dalam setiap gejala PIU (tabel 3). Pada bagian akhir, peneliti menjabarkan hasil penelitian dilihat dari data karakteristik partisipan.

Hasil analisa data menunjukkan ada gejala Problematic Internet Use (PIU) pada mahasiswa dari universitas di Jakarta pada tingkat sedang (moderate) $(\bar{X}=43.41)$. Hasil ini berarti mahasiswa dari universitas di Jakarta cenderung menggunakan internet untuk membuat perasaan mereka lebih baik ketika merasa murung dan merasa kesal, serta untuk melakukan interaksi sosial secara daring. Hasil penelitian ini tidak sesuai dengan beberapa hasil penelitian sebelumnya yang menyatakan bahwa mahasiswa cenderung mengalami gejala PIU pada tingkat di atas rata-rata (Tutgun \& Deniz, 2010). Penelitian Tutgun dan Deniz (2010) mengenai gejala PIU melibatkan partisipan penelitian secara spesifik yaitu mahasiswa dari Fakultas Ilmu Teknologi (IT) pada salah satu universitas di Turkey. Berbeda dengan hasil penelitian tersebut, pada studi ini gejala PIU ditemukan dalam kategori sedang (moderate) pada mahasiswa dari tiga universitas yang terdapat di wilayah Jakarta.

PIU memiliki empat karakteristik gejala, yaitu preference for online social interaction (POSI), mood regulation, dan deficient self-regulation yang mencakup dua konseptual, yaitu cognitive preoccupation dan compulsive internet use, serta gejala negative outcome. Setiap karakteristik gejala PIU akan dijelaskan secara satu per satu berdasarkan hasil penelitian.

Tabel 3.

Hasil Perhitungan Gejala-gejala PIU

\begin{tabular}{lll}
\hline Gejala-gejala PIU & Mean & Kategori \\
\hline $\begin{array}{l}\text { Preference for Online Social Interaction } \\
\text { Mood Regulation }\end{array}$ & 7.26 & Sedang \\
Deficient self-regulation: & 10.59 & Sedang \\
$\quad$ Cognitive Preoccupation & & \\
$\quad$ Compulsive Internet Use & 8.76 & Sedang \\
Negative Outcome & 9.07 & Sedang \\
\hline
\end{tabular}

Gejala utama yang ditemukan berhubungan dengan gejala kognitif dan gejala perilaku lainnya pada gejala PIU adalah POSI (Caplan, 2002). Hasil penelitian ini menunjukkan bahwa gejala POSI pada mahasiswa dari universitas di Jakarta tergolong sedang $(\bar{X}=7.26)$. Hal ini menunjukkan bahwa mahasiswa cenderung lebih memilih interaksi sosial secara daring daripada komunikasi secara tatap muka, terutama jika interaksi tatap muka tidak mungkin dilakukan. Hal ini menun- 
jukkan bahwa interaksi dan komunikasi secara daring merupakan pilihan yang situasional bagi mahasiswa. Hasil ini senada dengan pernyataan Papacharissi dan Rubin (2000) bahwa internet juga digunakan untuk kepentingan interpersonal yaitu sebagai alternatif interaksi tatap muka. Bahkan Shaffer et al. (2000) berpendapat bahwa internet memang menyajikan bentuk lain dari interaksi sosial dan hal ini memang memberikan kemudahan bagi penggunanya. Secara lebih spesifik, Davis (2001) mengungkapkan bahwa seseorang dapat mengembangkan POSI sebagai alternatif karena interaksi secara daring lebih aman, resikonya lebih kecil dan ia dapat berkomunikasi dengan lebih efektif jika komunikasi dilakukan secara daring. McKenna, Green, dan Gleason (2002) juga mengungkapkan bahwa seseorang yang kesepian juga cenderung merasa bahwa ia dapat mengekspresikan dirinya dengan lebih baik di internet daripada di dunia nyata.

Partisipan penelitian ini mengalami gejala mood regulation yang tergolong sedang $(\bar{X}=10.59)$. Hal ini menunjukkan bahwa mahasiswa cenderung menggunakan internet untuk meregulasi emosi dan perasaan negatif yang dirasakan. Mahasiswa menampilkan kecenderungan menggunakan internet untuk membuat perasaan mereka lebih baik ketika merasa murung, dan juga ketika mereka merasa kesal. Jika melihat tabel 2, chatting dan membuka situs sosial media adalah hal yang paling banyak dilakukan oleh mahasiswa. Hal ini saling berkaitan karena fasilitas chatting dan situs sosial media menjadi media utama untuk menyalurkan emosi atau perasaan negatif yang dirasakan mahasiswa. Bagi mahasiswa, penggunaan internet tersebut diharapkan dapat membantu membuat perasaan mereka menjadi lebih baik. Menurut Caplan (2010), ketika internet digunakan sebagai media eksklusif untuk meregulasi mood atau perasaan negatif seseorang, maka secara tidak sadar individu mengalami penggunaan internet yang kompulsif (compulsive internet use). Kondisi ini membuat regulasi mood atau perasaan negatif melalui penggunaan internet merupakan salah satu gejala kognitif dari PIU (Caplan, 2002, 2010; LaRose, Lin, \& Eastin, 2003). Namun kondisi ini tidak sepenuhnya dialami oleh seluruh partisipan sebab ada pula mahasiswa yang menggunakan internet untuk kepentingan lain dan bukan untuk menyalurkan perasaan. Penelitian Caplan (2003) juga menunjukkan bahwa ada banyak variasi keadaan yang membuat seseorang tidak selalu menggunakan internet untuk mengubah perasaannya menjadi lebih baik. Menurut Ramdhani (2007), kepribadian pun turut menentukan pilihan media berkomunikasi.

Gejala deficient self-regulation mempunyai dua konstruk, yaitu cognitive preoccupation (gejala kognitif), dan compulsive internet use (gejala perilaku) (Caplan, 2010). Untuk gejala cognitive preoccupation, partisipan termasuk dalam kategori sedang $(\bar{X}=8.76)$. Hal ini menunjukkan bahwa mahasiswa cenderung masih memikirkan hal-hal yang dapat dilakukan secara daring bahkan ketika sedang tidak tersambung dengan internet. Pemikiran ini kemudian mengacu pada obsesi untuk segera melakukan kegiatan yang berkaitan dengan internet. Meski tidak dialami oleh seluruh partisipan, namun gejala ini tampak pada kelompok mahasiswa yang gemar menggunakan internet untuk bermain game. Kelompok mahasiswa ini masih memikirkan hal-hal terkait dengan game yang mereka mainkan ketika sudah berhenti bermain. Kondisi ini kemudian memicu mereka untuk segera kembali 
bermain game. Walau demikian, pemikiran serta obsesi untuk segera daring yang dihadapi oleh kelompok mahasiswa tersebut tidak sampai mengganggu mereka dalam beraktivitas di dunia nyata. Meskipun gejala cognitive preoccupation yang dirasakan partisipan tergolong sedang namun hal ini perlu mendapat perhatian mengingat Davis (2001) menemukan bahwa jika pemikiran atau obsesi pada internet mendapatkan penguatan, maka lingkaran setan ini dapat menimbulkan masalah yang lebih besar karena seseorang menghabiskan banyak waktu untuk daring. Secara umum, Kubey, Lavin \& Barrows (2001) menyatakan bahwa gejala deficient selfregulation pada PIU mampu menyebabkan resiko negatif pada kehidupan sehari-hari seseorang, seperti individu kesulitan menjalin relasi sosial, prestasi akademis menurun, dan lain sebagainya.

Gejala compulsive internet use yang dialami partisipan berada pada kategori sedang $(\bar{X}=9.07)$. Hal ini menunjukkan bahwa mahasiswa cenderung sulit mengontrol diri untuk membatasi perilaku penggunaan internet mereka. Berdasarkan hasil analisa data, mahasiswa berusia 17 20 tahun cenderung tidak kesulitan mengatur perilaku penggunaan internet mereka. Di sisi lain, mahasiswa berusia 21 - 26 tahun cenderung mengalami kesulitan dalam mengatur perilaku penggunaan internet serta dorongan untuk selalu daring. Penemuan ini tidak sejalan dengan penelitian sebelumnya (Morahan-Martin \& Schumacher, 2000; Scherer, 1997) yang menyatakan bahwa mahasiswa yang berusia lebih muda cenderung menunjukkan gejala penggunaan internet secara kompulsif daripada mahasiswa yang berusia lebih dewasa.

Lebih lanjut ditemukan bahwa dalam penelitian ini, mahasiswa yang cenderung kesulitan mengatur perilaku penggunaan internet adalah mereka yang menggunakan internet untuk bermain game secara daring. Alasan utama mahasiswa mengalami kecenderungan penggunaan internet secara kompulsif pada penelitian ini sejalan dengan penelitian tokoh sebelumnya, yang juga menyatakan bahwa game daring merupakan alasan seseorang cenderung mengalami compulsive internet use (Meerkerk, Van Den Eijnden, \& Garretsen, 2006).

Hasil penelitian menunjukkan bahwa partisipan mengalami gejala negative outcome dalam kategori sedang $(\bar{X}=7.74)$ yang berarti penggunaan internet untuk melakukan berbagai aktivitas secara daring dirasakan tidak mengganggu kehidupan sehari-hari mereka. Meskipun pada kelompok mahasiswa berusia 17 - 20 tahun cenderung pernah melewatkan acara-acara sosial karena penggunaan internet namun dampak penggunaan internet tersebut diyakini tidak memberikan dampak negatif yang berpengaruh terhadap kehidupan sehari-hari mahasiswa. Penelitian Kraut et al (2002) pun menyimpulkan, internet tidak memiliki efek yang berbahaya pada kesejahteraan psikologis seseorang dan bahkan jumlah pertemanan seseorang dapat bertambah karena teman yang ditemukan di dunia maya. Walau demikian, gejala ini perlu diwaspadai sebab Caplan (2005) menemukan bahwa gejala ini dapat mengarah pada dampak negatif pada kehidupan sosial dan performa akademis yang diakibatkan oleh penggunaan internet individu.

Variabel PIU juga dibahas dalam kaitannya dengan data demografis partisipan, yaitu jenis kelamin, lama penggunaan internet, serta aktivitas penggunaan internet. Berdasarkan jenis kelamin, PIU dianalisa menggunakan independent t-test, 
dengan $\mathrm{p} /$ Sig. sebesar 0.333. Hal ini menunjukkan tidak ada perbedaan gejala PIU yang signifikan antara mahasiswa laki-laki dan perempuan di Jakarta. Baik kelompok mahasiswa laki-laki maupun perempuan dari universitas di Jakarta cenderung menggunakan internet untuk meregulasi emosi dan perasaan agar menjadi lebih baik ketika sedang murung dan kesal. Hasil ini tidak sesuai dengan penelitian sebelumnya (Li \& Chung, 2006; Tahiroğlu, Çelik, Uzel, Özcan, \& Avcı, 2008) yang menemukan adanya perbedaan PIU antara mahasiswa laki-laki dengan mahasiswa perempuan. Mahasiswa lakilaki dilaporkan cenderung menampilkan POSI, cognitive preoccupation, dan negative outcome, sedangkan mahasiswa perempuan cenderung menampilkan penggunaan internet untuk mood regulation.

Berdasarkan lama penggunaan internet, PIU dianalisa menggunakan one-way ANOVA, dengan $\mathrm{p} /$ Sig. hitung sebesar 0.480. Hal ini menunjukkan tidak ada perbedaan gejala PIU yang signifikan pada mahasiswa dari universitas di Jakarta ditinjau berdasarkan lama penggunaan internet mereka, baik yang menggunakan internet selama $\leq 30$ menit maupun $\geq 3$ jam. Hasil analisa ini tidak sesuai dengan beberapa hasil penelitian sebelumnya (Anderson, 2001; Caplan, 2005; Davis, 2001; Young, 1996) yang menemukan bahwa jika lama penggunaan internet meningkat maka kecenderungan PIU pun meningkat. Meski demikian, hasil penelitian ini selaras dengan temuan Kraut et al (2002). Pada tahun 1998, Kraut et al menemukan korelasi yang signifikan antara lama menggunakan internet per minggu dengan depresi dan kesepian, namun dalam survei lanjutan setelah 3 tahun pada partisipan yang sama, gejala tersebut tidak tampak (Kraut et al, 2002).
Berdasarkan aktivitas penggunaan internet, pada penelitian ini internet digunakan sebagai media perantara bagi mahasiswa untuk melakukan kegiatan-kegiatan seperti mencari informasi akademis, membuka e-mail pribadi, mencari hiburan secara daring (game online, streaming musik dan video, dan lain-lain), bersosialisasi dengan orang lain (membuka situs social media, chatting, group chat), maupun untuk online shopping. Hasil penelitian Meerkerk, van den Ejinden, dan Garratsen (2006) mengindikasikan bahwa penggunaan internet dalam frekuensi yang tinggi/ sering terutama untuk membuka situs pornografi dan bermain game online dapat menjadi faktor sekunder yang signifikan dalam mengembangkan gejala PIU. Kondisi akan berubah sebaliknya jika internet digunakan untuk melakukan kegiatan lain di luar mengakses pornografi, seperti mencari informasi akademis, membuka situs sosial media, dan kegiatan daring lainnya. Oleh karena itu, disimpulkan bahwa gejala PIU dapat muncul dan berkembang berdasarkan konten spesifik yang diakses oleh individu melalui internet (khususnya game daring dan juga situs pornografi). Partisipan penelitian ini mengindikasikan bahwa mereka lebih sering menggunakan internet untuk melakukan aktivitas sosial secara daring, seperti membuka situs social media, chatting, dan group chat. Oleh karena itu, faktor aktivitas penggunaan internet pada penelitian ini tidak dapat berperan sebagai faktor sekunder yang signifikan dapat memengaruhi gejala PIU pada mahasiswa dari universitas di Jakarta.

\section{Kesimpulan}

Artikel ini melaporkan hasil penelitian mengenai gambaran PIU pada mahasiswa di Indonesia, khususnya di Jakarta yang menunjukkan bahwa gejala PIU pada 
mahasiswa dari universitas di Jakarta berada pada tingkat sedang. Hal ini ditandai dengan gejala POSI, mood regulation, cognitive preoccupation, compulsive internet use, dan negative outcome yang juga berada dalam kategori sedang. Berdasarkan jenis kelamin, tidak terdapat perbedaan gejala PIU yang signifikan antara mahasiswa laki-laki dan perempuan di Jakarta. Berdasarkan faktor lama penggunaan internet, tidak terdapat perbedaan gejala PIU yang signifikan pada mahasiswa dari universitas di Jakarta.

\section{Saran}

Peneliti menyadari banyak kekurangan dalam penelitian ini sehingga diharapkan penelitian selanjutnya dapat mengaitkan PIU dengan variabel psikologis lain, seperti regulasi emosi atau mood. Penelitian selanjutnya juga dapat meneliti lebih lanjut mengenai perbedaan gejala PIU antara mahasiswa laki-laki dengan mahasiswa perempuan di Indonesia, mengingat adanya perbedaan antara hasil penelitian ini dengan penelitian sebelumnya. Peneliti selanjutnya juga dapat memperbanyak jumlah partisipan dan juga memperluas wilayah pengambilan sampel sehingga hasil lebih dapat merepresentasikan karakteristik mahasiswa di Indonesia.

Masukan yang dapat diberikan kepada pihak universitas, pemerintah dan masyarakat umum adalah pentingnya membatasi aktivitas di internet, terutama jika aktivitas tersebut melibatkan game online dan mengakses konten pornografi. Hal ini perlu diperhatikan sebab menghabiskan banyak waktu untuk kedua aktivitas tersebut dapat membawa lebih banyak pengaruh negatif seperti mengganggu relasi sosial hingga gangguan kognisi yang dapat menyebabkan gangguan perilaku.

\section{Kepustakaan}

Amichai-Hamburger, Y., \& Ben-Artzi, E. (2003). Loneliness and internet use. Computers in Human Behavior, 19, 7180.

Anderson, K. J. (2001). Internet use among college students: An explanatory study. Journal of American College Health, 50, 21-26. http://dx.doi.org/ 10.1080/07448480109595707.

Azwar, S. (2013). Metode penelitian. Yogyakarta: Pustaka Pelajar

Caplan, S. E. (2002). Problematic Internet use and psychosocial well-being: Development of a theory-based cognitive-behavioral measure. Computers in Human Behavior, 18, 533-578. doi: 10.1016/j.chb.2009.06.006.

Caplan, S. E. (2003). Preference for online social interaction: A theory of problematic internet and psychological wellbeing. Communication research, 30, 625648. doi: $10.1177 / 0093650203257842$.

Caplan, S. E. (2010). Theory and measurement of generalized problematic internet use: A two-step approach. Computers in Human Behavior, 26(5), 1089-1097. doi: 10.1016/j.chb.2010.03.01 2.

Caplan, S., Williams, D., \& Yee, N. (2009). Problematic Internet use and psychosocial well-being among $\mathrm{MMO}$ players. Computers in Human Behavior, Volume 25, Issue 6, November 2009, Pages 1312-1319. doi: 10.1016/j.chb.2009.06. 006

Caplan, S. E. (2005). A social skill account of problematic internet use. Journal of Communication, 55, 721-736. doi: 10.1111/j.1460-2466.2005.tb03019.x

Caplan, S. E., \& High, A. C. (2006). Beyond excessive use: The interaction between cognitive and behavioral symptoms of 
problematic Internet use. Communication Research Reports, 23, 265-271. doi: 10.1080/08824090600962516.

Chen, Y. F., \& Peng, S. S. (2008). University students' internet use and its relationship with academic performance, interpersonal relationships, psychosocial adjustment, and self-evaluation. CyberPsychology \& Behavior, 11(4), 467469. doi: 10.1089/ cpb.2007.0128.

Chou, C., \& Hsiao, M. C. (2000). Internet addiction, usage, gratifi cation, and pleasure experience: The Taiwan college students' case. Computers \& Education, 35, 65-80. doi: 10.1016/ S0360-1315(00)00019-1.

Chou, C., Condron, L., \& Belland, J. C. (2005). A review of the research on internet addiction. Educational Psychology Review, 17(4), 363-388. doi: 10.1007/s10648-005-8138-1.

Czincz, J., \& Hechanova, R. (2009). Internet addiction: Debating the diagnosis. Journal of Technology in Human Services, 27(4), 257-272. doi: $10.1080 / 15228830903329815$.

Davis, R. A. (2001). A cognitive-behavioral model of pathological internet use. Computer in Human Behavior, 17: 187195. doi: 10.1016/S0747-5632(00)000418.

Davis, R. A. (2002). What is internet addiction? Available at: www.victoriapoint.com/internetaddict ion/articles.htm.

Hall, A. S., \& Parsons, J. (2001). Internet addiction: College student case study using best practices in cognitive behavior therapy. Journal Mental Health Couns, 23: 312-327.

Kandell, J. J. (1998). Internet addiction on campus: The vulnerability of college students. Cyberpsychology \& Behavior, Cilt: 1, ss.11-17. doi: 10.1089/ cpb.1998.1.11.

Kraut, R., Kiesler, S., Boneva, B., Cummings, J., Helgeson, V.,\& Crawford, A. (2002). Internet paradox revisited. Journal of Social Issues, 58, 4974. doi: 10.1111/1540-4560.00248.

Kraut, R., Patterson, M., Lundmark, V., Kiesler, S., Mukopadhyay, T., \& Scherlis, W. (1998) Internet paradox: A social technology that reduces social involvement and psychological wellbeing? American Psychologist, 53, 10171031. doi: 10.1037/0003-066X.53.9.1017

Kubey, R. W., Lavin, M. J., \& Barrows, J. R. (2001). Internet use and collegiate academic performance decrements: Early findings. Journal of Communication, 51, 366-382.

LaRose, R., Lin, C.A., \& Eastin, M.S. (2003). Unregulated Internet usage: Addiction, habit, or deficient self-regulation? Media Psychology, 5, 225-253.

Li, S. M. \& Chung, T. M. (2006). Internet function and internet addictive behavior. Computers in Human Behavior, 22, 1067-1071.

McKenna, K. Y. A., Green, A. S., \& Gleason, M. E. J. (2002). Relationship formation on the Internet: What's the big attraction? Journal of Social Issues, 58(1), 9-31. doi: 10.1111/15404560.00246 .

Meerkerk, G. J., Van Den Eijnden, R. J., \& Garretsen, H. F. (2006). Predicting compulsive Internet use: It's all about sex! Cyberpsychology \& Behavior, 9, 95103. doi: $10.1089 / \mathrm{cpb} .2006 .9 .95$

Moore, D. (1995). The emperor's virtual clothes: the naked truth about the Internet culture. Chapel Hill: Alogonquin, NC

Morahan-Martin, J. (2007). Internet use and abuse and psychological problems. Oxford handbook of Internet psychology (pp. 331-345). New York: 
Oxford University Print. doi: 10.1093/ oxfordhb/9780199561803.013.0021.

Morahan-Martin, J., \& Schumacher, P. (2000). Incidence and correlates of pathological internet use among college students. Computer-Human Behaviour, 16, 13-29. doi: 10.1016/ S0747-5632(99)00049-7.

Mossbarger, B. (2008). Is internet addiction addressed in the classroom? A survey of psychology textbooks. Computers in Human Behavior, Cilt: 24.ss.468-474. doi: 10.1016/j.chb.2007.02.002.

Murali, V., \& George, S. (2007). Lost online: an overview of internet addiction. Advances in Psychiatric Treatment, 13(1), 24-30. doi: 10.1192/ apt.bp.106.002907.

Özcan, N. K. \& Buzlu, S. (2007). Internet use and its relation with the psychosocial situation for a sample of university students. Cyberpsychology $\mathcal{E}$ Behavior, 10(6), 767-772. doi: 10.1089/ cpb.2007.9953.

Papacharissi, Z., \& Rubin, A. M. (2000). Predictors of Internet use. Journal of Broadcasting and Electronic Media, 44, 175-196. http://dx.doi.org/10.1207/ s15506878jobem4402_2.

Ramdhani, Neila. (2007). Apakah kepribadian menentukan pemilihan media komunikasi? Metaanalisis terhadap hubungan kepribadian extraversion, neuroticism, dan openness to experience dengan penggunaan email. Jurnal Psikologi, 34(2), 112-129.

Ramdhani, Neila. (2016). Emosi moral dan empati pada pelaku perundungansiber. Jurnal Psikologi, 43(1) 66-80.

Scherer, K. (1997). College Life On-Line: Healthy and Unhealhty Internet Use. Journal of College Student Development, Cilt:38, ss.655-665.
Shaffer, H. J., Hall, M. N., \& Vander Bilt, J. (2000). "Computer addiction": a critical consideration. American Journal of Orthopsychiatry, 70, 162-168. doi: 10.1037/h0087741.

Shapira, N. A., Lessig, M. C., Goldsmith, T. D., Szabo, S. T., Lazoritz, M., Gold, M. S., \& Stein, D. J. (2003). Problematic internet use: proposed classification and diagnostic criteria. Depression and anxiety, 17(4), 207-216. Doi: 10.1002/ da.10094.

Spada, M. M., Langston, B., Nikčević, A. V., \& Moneta, G. B. (2008). The role of metacognitions in problematic internet use. Computers in Human Behavior, 24, 2325-2335. doi: 10.1016/ j.chb.2007.12.002.

Suhail, K., \& Bargess, Z. (2006). Effects of excessive Internet use on undergraduate students in Pakistan. Cyber PsychologyEBehavior, 9, 297-307. doi:10.1089/cpb.2006.9.297.

Tahiroğlu, A. Y., Çelik, G. G., Uzel, M., Özcan, N. \& Avcl, A. (2008). Internet use among Turkish adolescents. Cyberpsychology \& Behavior, 11(5), 241246. doi: 10.1089/cpb.2007.0165.

Tutgun, A., \& Deniz, L. (2010). Problematic Internet Usage among Prospective Teachers. International Educational Technology Conference (IETC) 2010, Volume II, Page 1226, Bogazici University, Istanbul.

Van den Eijnden., Regina, J. J. M., Meerkerk, Gert-Jan., Vermulst, Ad A., Spijkerman, Renske., Engels, Rutger C. M. E. (2008). Online communication, compulsive internet use, and psychosocial well-being among adolescents: A longitudinal study. Developmental Psychology, 44, pp. 655-665.

Ybarra, M.L., Alexander, C., Mitchell, K.J. (2005). Depressive symptomatology, 
youth internet use, and online interactions: A national survey. Journal of Adolescent Health, 36, pp. 9-18. doi:10.1016/j.jadohealth.2003.10.012.

Young K. (1997). What makes the internet addictive: potential explainations for pathological internet use. Paper presented at the Annual Conference of The American Psychological Association, Chicago.

Young, K. S. (1996). Caught in the net: how to recognize the signs of Internet addiction-and a winning strategy for recovery. New York: Wiley.

Young, K. S. (1998). Internet addiction: the emergence of a new clinical disorder. Cyberpsychology and Behavior, 1(3), 237-
244. doi: 10.1089/cpb.1998.1.237.

Young, K. S., \& Rogers, R. C. (1998). The relationship between depression and internet addiction. Cyberpsychology $\mathcal{E}$ Behavior, 1, 25-28. doi: 10.1089/ cpb.1998.1.25.

Yu-Yuan, L. (2007). Psycho-social related factors of junior high school students with internet addiction disorder. Chinese Journal of Clinical Psychology, 15, 422-423.

Zhang, L., Amos, C., \& McDowell, W.C. (2008). A Comparative Study of Internet Addiction between the United States and China. Cyber Psychology $\mathcal{E}$ Behavior, 11(6): 727-729. doi: 10.1089/ cpb.2008.0026. 